\title{
Termoplastia bronquial en el tratamiento del asma severa
}

\section{Bronchial thermoplasty in the treatment of severe asthma}

Isabel Palacios-Ortega, MD¹. Adnan Majid MD., FCCP²

'Internista, Neumóloga Universidad Javeriana. Bogotá, Colombia.

Neumóloga intervencionista, Centro Médico Imbanaco. Cali, Colombia.

${ }^{2}$ Director, Section of Interventional Pulmonology. Beth Israel Deaconess Medical Center. Associate Professor of Medicine. Harvard Medical School, Boston, Massachussets.

Correspondencia: Isabel Palacios. Correo electrónico: isabel.palacios@imbanaco.com.co Recibido: 26/10/14, Aceptado: 10/12/14.
La termoplastia bronquial es un procedimiento endoscópico innovador, que se usa para el tratamiento de pacientes con asma severa refractaria $(1,2)$.

Se trata de la reducción del músculo liso bronquial mediante la aplicación de energía por radiofrecuencia, hasta $18 \mathrm{~W}$, a través de un catéter introducido por el broncoscopio, que tendrá contacto con la pared bronquial $(1,2)$.

El catéter tiene un diámetro mínimo de $3 \mathrm{~mm}$, con el cual se logra incidir en la vía aérea desde los 3 $\mathrm{mm}$, hasta los $10 \mathrm{~mm}$ con la máxima apertura del mismo, deslizándolo y abriéndolo de distal a proximal cada $5 \mathrm{~mm}$ con el objetivo de no afectar sectores ya tratados $(1,2)$.

A la fecha, en América Latina se han reportado casos en Chile (3) y Brasil (4).

Se presentan las imágenes de un paciente de 54 años de edad, con asma severa refractaria, quien ha finalizado las tres sesiones de termoplastia requeridas. Se muestran imágenes de la broncoscopia terapéutica, con apertura del catéter de termoplastia haciendo contacto con la pared bronquial.

La imagen A corresponde a la primera sesión en la que se trató el lóbulo inferior derecho. La B es la
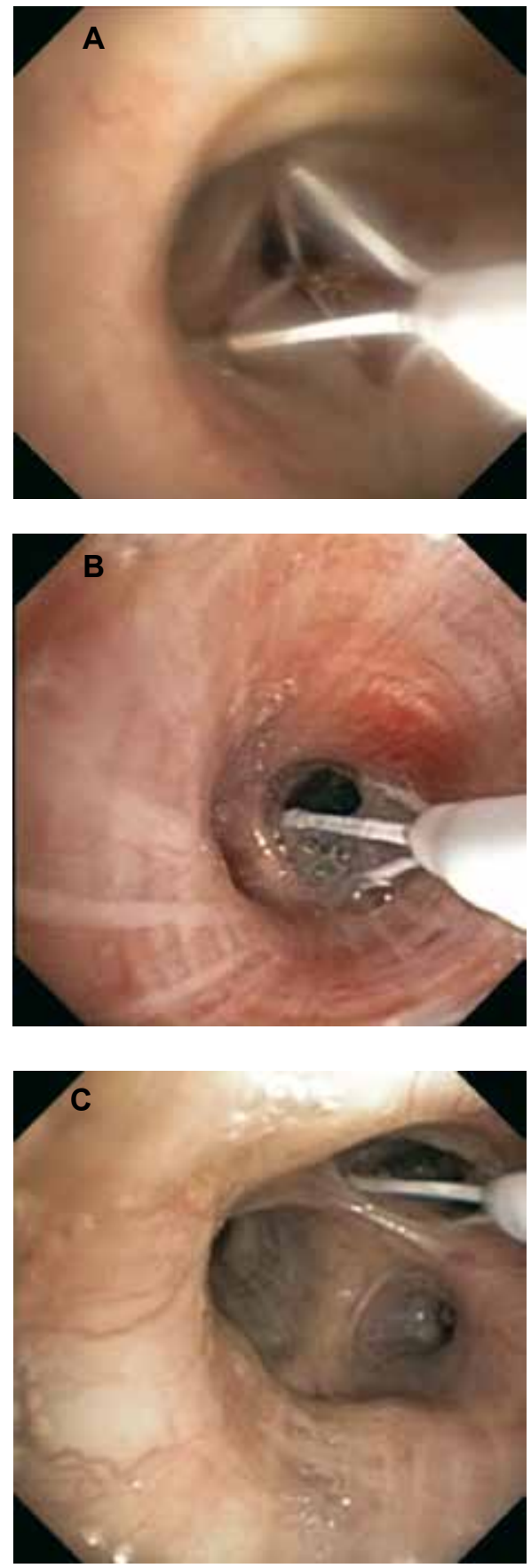
segunda sesión de tratamiento en la que se intervino el lóbulo inferior izquierdo. La $\mathrm{C}$, constituye la tercera sesión, en la que se trataron los lóbulos superiores. La imagen muestra el segmento apical del lóbulo superior derecho.

\section{Bibliografía}

1. Ajay S, Castro M, Chen A. Bronchial thermoplasty: a novel therapy for severe asthma. Clin Chest Med. 2013;34:437-44.
2. Dombret MC, Alagha K, Philippe Boulet L, Yves Brillet P, Joos G, Laviolette $\mathrm{M}$, et al. Bronchial thermoplasty: a new therapeutic option for the treatment of severe, uncontrolled asthma in adults. Eur Respir Rev. 2014;23:510-8.

3. Fernández-Bussy S, Labarca G, Caviedes I, Folch E, Majid A. Bronchial thermoplasty for severe asthma: Initial experience in Chile. Arch Bronconeumol. 2014.pii:S0300-2896(14)00352-4.

4. Rubin AS, Cardoso PF. Bronchial thermoplasty: report on the first endoscopic treatment for asthma in Latin America. J Bras Pneumol. 2008;34:59-62. 